\title{
STUDI PENGEMBANGAN PERBANKAN SYARIAH DI INDONESIA: MENGAPA MASYARAKAT TIDAK MEMILIH BANK SYARIAH?
}

\author{
Rahayu Saraswati \\ Bekerja diBess Finance \\ MB Hendrianto \\ Fakultas Ekonomi Universitas Islam Indonesia \\ e-mail: hendrie@fe.uii.ac.id
}

\begin{abstract}
Indonesia has been developing Islamic Banking since 1992. As the biggest muslim population in the world, it is expected that Islamic bank will have a significant role in the whole national banking system. A number of regulations have been issued by government and Bank Indonesia to accelerate the growth of Islamic Banking. Two most influential Islamic organizations -Majelis Ulama Indonesia and Muhammadiyah- have also issued fatwa on the haramness of interest and interest based banking. The fact shows, however, that the growth of Islamic Banking is not as fast as expected. Although having above national growth rate, Islamic banking is still minority to the whole national banking system. For instance, in 2010 the asset proportion of Islamic banking is still less than 3 percent of national banking asset. The aim of this paper is to identify the problems and challenges of the growth of Islamic banking in Indonesia. More specific, a survey has been conducted to identify factors influencing society not to choose Islamic banking products. The result shows that most of society are conventionally rational. Religious aspects have nothing to do with choice decision. They did not choose Islamic banking products because of economic factors such as quality of services, pricing, banking technology, and office location. This findings conclude that exploitation of religious aspect to develop Islamic Banking is less relevant
\end{abstract}

Keywords: Islamic banking, rational, economic factor, religious aspects

\section{PENDAHULUAN}

Perkembangan perbankan syariah di Indonesia dalam satu tahun terakhir memang menunjukkan fakta mengagumkan (Bank Indonesia, 2011). Pertumbuhan asset, pembiayaan, penghimpunan dana masyarakat senantiasa berada pada tingkatan di atas rata-rata perbankan nasional. Selama lima tahun terakhir rata-rata pertumbuhan industry perbankan syariah tak kurang dari $37.9 \%$ pertahun dengan tingkat Financing to Deposit Ratio (FDR) cukup tinggi, yaitu $89.67 \%$ pada Desember 2010. Tingkat pembiayaan bermasalah (Non Performing Financing (FDR) juga rendah, yaitu $3.02 \%$. Jika pada tahun 1999 baru terdapat 3 Bank Umum Syariah (BUS) maka pada tahun 2010 telah menjadi 11 buah. Hampir semua bank umum memiliki Unit Usaha Syariah (UUS) sehingga pada tahun 2010 terdapat 23 UUS. Kantor BUS dan UUS mencapai 1.763 buah dengan tingkat pertumbuhan sebesar 44, 5 \% (2010) lihat Tabel 1.

Tabel 1: Statistik Bank Islam Indonesia 2009 - 2010

\begin{tabular}{lrr}
\hline & $\mathbf{2 0 0 9}$ & $\mathbf{2 0 1 0}$ \\
\hline Bank Umum Syariah (BUS) & 6 & $\mathbf{1 1}$ \\
Unit Usaha Syariah (UUS) & 25 & $\mathbf{2 3}$ \\
Bank Perkreditan Rakyat Syariah & 139 & $\mathbf{1 5 0}$ \\
BUS \& UUS Kantor & 1.223 & $\mathbf{1 . 7 6 3}$ \\
Pertumbuhan Kantor & $19,5 \%$ & $\mathbf{4 4 , 5 \%}$ \\
\hline
\end{tabular}


Sumber: Bank Indonesia, 2011

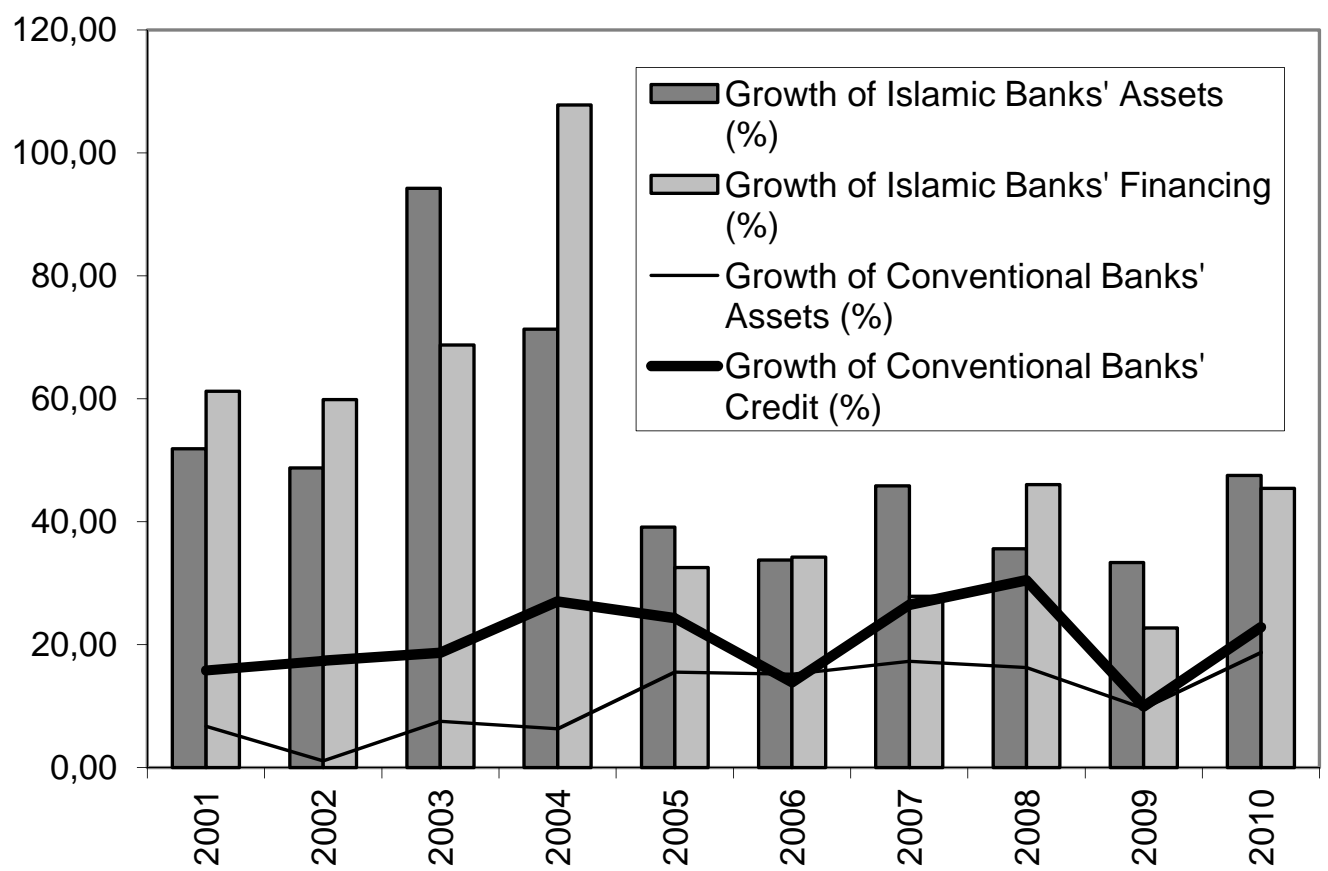

Sumber: Bank Indonesia, 2011

Gambar 1: Pebandingan Per tumbuhan Aset dan Pembiayaan Bank Islam dan Bank Konvensional

Sementara itu dari sisi asset dan pembiayaan pertumbuhannya senantiasa melampaui tingkat pertumbuhan perbankan konvensional selama satu dasawarsa terakhir. Rata-rata pertumbuhan asset perbankan syariah tak kurang dari $37,5 \%$ per tahun, jauh di atas perbankan konvensional yang selalu di bawah $20 \%$ pertahun.

Meskipun demikian kinerja keuangan perbankan syariah ini sebenarnya masih jauh yang diharapkan. Dengan tingkat pertumbuhan saat ini, peranan perbankan syariah tetap masih kecil dibandingkan dengan perbankan nasional. Porsi asset maupun pembiayaan perbankan syariah masih di bawah $3 \%$ dibandingkan dengan perbankan nasional. Porsi ini tentu saja masih jauh dari yang diharapkan mengingat penduduk muslim, yang sebenarnya merupakan segmen utama konsumen perbankan syariah, adalah mayoritas. Bank Indonesia telah menetapkan suatu target directive pencapaian porsi asset sebesar $5 \%$ pada tahun
2008 namun faktanya saat ini target ini tidak tercapai. Pencapaian target ini dilakukan dengan Program Akselerasi Pengembangan Perbankan Syariah 20072008 yang meliputi serangkain rencana komperehensif untuk mempercepat perkembangan perbankan syariah.

Selain itu pertumbuhan asset perbankan syariah sebenarnya mengikuti pola pertumbuhan teoritik, di mana pada masa awal (infant) menuju kedewasaan (mature) selalu terjadi kenaikan pertumbuhan. Setelah mencapai kedewasaan akan diikuti oleh masa kemapanan (steady) sebelum pada akhirnya terjadi penurun (decline). Mencermati pola pertumbuhan akhir-akhir ini patut diajukan sebuah kekhawatiran terjadinya percepatan tahap kemapanan atau bahkan penurunan. Usia perbankan syariah di Indonesia yang baru sekitar satu dasawarsa tentu belum layak mencapai tahap steady atau bahkan decline sebagaimana dalam kenyataan saat ini.

Mencermati kegagalan pencapai target perkembangan perbankan syariah di 
Indonesia patut diajukan pertanyaan tentang mengapa masyarakat kurang responsive terhadapnya. Alasan-alasan emosional relijius terbukti tidak berhasil mendorong masyarakat muslim untuk menggunakan jasa perbankan syariah. Penerbitan fatwa Majelis Ulama Indonesia tentang haramnya bunga bank, yang kemudian juga diikuti oleh Muhammadiyah, ternyata tidak membuat masyarakat meninggalkan bank konvensional. Oleh karenanya menarik untuk diteliti tentang mengapa masyarakat tidak memilih menggunakan produkproduk bank syariah. Patut diduga bahwa masyarakat bersikap rasional-ekonomis dalam memilih produk-produk perbankan, artinya pertimbangan-pertimbangan seperti biaya, manfaat, layanan, teknologi dan faktor-faktor ekonomis lainnya lebih mendominasi dibandingkan pertimbangan keagamaan.

Penelitian-penelitian yang ada selama ini cenderung melihat aspek-aspek yang mempengaruhi masyarakat memilih perbankan syariah. Hafeez dan Ahmed (2008) menemukan bahwa faktor penting bagi nasabah dalam memilih bank di Pakistan adalah lokasi bank yang dekat dengan tempat tinggal atau tempat kerja dan kemudahan akses yang diberikan oleh bank berupa fasilitas online serta tempat parkir yang luas. Di sisi lain, penggunaan Bahasa Inggris bukan menjadi alasan untuk pemilihan bank. Kesimpulan ini sejalan dengan temuan Subhani, et.al, 2012. Penelitian ini penting mengingat Pakistan adalah salah satu dari tiga Negara (Sudan, Iran, Pakistan) yang melakukan reformasi total dalam system perbankannya, di mana semua bank diharuskan beroperasi secara syariah.

Dalam negara yang menerapkan sistem ganda di mana bank konvensional beroperasi bersama-sama bank syariah ternyata banyak masyarakat yang tidak memahami dengan baik perbedaan bank syariah dengan bank konvensional. Hal ini terjadi tidak hanya terjadi di Negaranegara sekuler tetapi juga Negara Islam dan atau Arab. Akibatnya, masyarakat cenderung menggunakan rasionalitas ekonomis belaka di dalam memilih produkproduk perbankan. Jorg Bley (2009) melakukan penelitian tentang persepsi mahasiswa terhadap keuangan Islam dan keuangan konvensional di United Arab Emirates. Berdasarkan hasil analisis menunjukkan bahwa mahasiswa dan lulusan mahasiswa lebih memahami konsep keuangan konvensional daripada konsep keuangan Islam, Penggunaan pelabelan produk dan jasa dengan istilah bahasa Arab menghalangi pemahaman keuangan islam. Mahasiswa non muslim menganggap keuangan islam hanya diperuntukan untuk orang islam dan kurangnya pelayanan dan promosi produk unggulan. Faktor penentu terhadap ketertarikan keuangan Islam lebih karena kondisi bank.

Kesimpulan yang sejenis juga ditemukan di Malaysia. Norafifah and Haron (2001) menemukan bahwa produkproduk perbankan Islam tidak populer di kalangan konsumen korporat, meskipun perbankan syariah yang telah didirikan di Malaysia lebih dari 15 tahun. Sebagian besar responden mulai memanfaatkan fasilitas bank syariah kurang dari lima tahun. Responden memiliki pengetahuan dalam sistem perbankan Islam tetapi pada saat ketika terdapat pertanyaan lebih mendalam tentang prinsip-prinsip yang digunakan dalam sistem perbankan Islam yang diajukan dan sifat-prinsip pembagian keuntungan dalam perbankan Islam mereka kurang memahami.

Hasil lebih tegas diperoleh Haque et.al (2009) dalam penelitian tentang faktor yang mempengaruhi mahasiswa memilih bank syariah di Malaysia. Ia menyimpulkan bahwa mudahnya akses informasi, kualitas pelayanan, perspektif agama, kegiatan sosial, membuat perbankan syariah semakin mudah dan banyak diminati. Di Malaysia, kesesuaian dengan syariah banyak dipersepsikan sebagai faktor pembuka bagi masyarakat untuk 
memilih bank syariah sebelum mempertimbangkan faktor-faktor lain sebagaimana bank pada umumnya (Abduh, Muhammad dan Omar, 2012; Marimuthu, et.al. 2010, Dusuki, 2007)

Hasil-hasil penelitian lokal di Indonesia menunjukkan hasil yang tidak berbeda. Rais (2008) menemukan bahwa kebanyakan masyarakat belum memahami perbankan syariah dan segala aspek syariah yang berkenaan dengan bank dan ekonomi. Meskipun responden penelitian tersebut adalah mahasiswa, tetapi hal ini menggambarkan kondisi masyarakat luas sebab mahasiswa adalah kelompok yang seharusnya paling memahami perbankan syariah. Dengan gambaran tersebut maka tidaklah mengherankan kesimpulan bahwa mayoritas masyarakat Indonesia tidak terlalu menggunakan pertimbangan emosional relijus di dalam memilih perbankan. Alfi (2009) menemukan bahwa segmen Floating More Syariah merupakan target pasar yang paling potensial, sementara segemen Syariah Loyalis hanya kecil.

Penelitian pada masyarakat muslim di Daerah Istimewa Yogyakarta juga menunjukkan bahwa mereka yang menganggap bahwa menyimpan uang di bank konvensional memiliki rasa lebih aman adalah lebih banyak dibandingkan yang menganggap bahwa menyimpan di bank syariah lebih aman (Bank Indonesia, 2003). Penelitian Lestari (2006) memperluas kesimpulan ini di mana popularitas, kemudahan akses bank syariah dan pelayanan, persepsi masyarakat tentang bunga, fasilitas dan pilihan produk serta pelayanan mempengaruhi keputusan masyarakat dalam memilih bank syariah.

Penelitian ini bertujuan untuk mengetahui mengapa masyarakat muslim tidak memilih perbankan syariah. Penelitian tentang alasan tidak memilih ini penting karena: (a) untuk mempertegas alasan tentang tidak menggunakan bank syariah; dan (b) untuk menguji konsistensi alasan memilih di mana temuan menunjukkan dominasi pertimbangan rasional ekonomi. Variabel relijiusitas dan non relijiusitas akan diuji sebagai faktor yang mempengaruhi keputusan masyarakat tidak memilih bank syariah.

\section{METODOLOGI PENELITIAN}

Penelitian ini merupakan hasil survey terhadap masyarakat kota Yogyakarta. Pemilihan kota Yogyakarta didasarkan atas pertimbangan kota ini sebagai kota pendidikan dengan basis relijiusitas Islam dan Jawa yang mengakar. Keadaan ini memenuhi syarat untuk mendapatkan karakter sikiap masyarakat yang rasional atau emosional dalam memilih produk bank. Data diperoleh melalui wawancara mendalam (indepth interview) dan kuesioner yang berasal dari responden terpilih. Responden dipilih menggunakan metode cluster sampling atau multi-stage sampling yang terdiri atas mahasiswa, pekerja sektor formal dan sektor informal di Kota Yogyakarta yang menggunakan fasilitas jasa perbankan. Dengan memperhatikan komposisi tersebut maka responden mahasiswa sejumlah $45 \%$, pekerja sektor formal sebesar $35 \%$ dan pekerja sektor informal sebesar $50 \%$.

Analisis data dilakukan dengan menggunakan model logit (Gujarati, 2001). Bentuk rumus umum keputusan masyarakat dalam memilih bank syariah:

$$
\begin{aligned}
L_{i} & =\ln \left[\frac{P_{i}}{1-P_{i}}\right]=\beta o+\beta_{i} X_{i}+u_{i} \\
Y= & \beta_{o}+\beta_{1} X_{1}+\beta_{2} X_{2}+\beta_{3} X_{3}+\beta_{4} X_{4}+\beta_{5} X_{5}+ \\
& u_{i}
\end{aligned}
$$

Keterangan:

$Y=$ Keputusan masyarakat muslim

$L_{i}=$ Keputusan masyarakat muslim tidak memilih bank syariah di Yogyakarta, dimana $L i=0$, berarti diluar tidak memilih dan $L i=1$, berarti tidak memilih

$X_{i}=$ independent variabel, dimana $X_{1}=$ Relijiusitas; $X_{2}=$ tingkat bagi hasil; $X_{3}=$ fasilitas dan pelayanan; $X_{4}=$ hadiah dan $X_{5}=$ lokasi. 
$\beta_{o}=$ konstanta, dan $u_{i}=$ gangguan

$\beta_{i}=$ koefisien regresi dari masing masing variabel independent

$P_{i}=$ probabilitas, yaitu peluang kejadian.

Masing-masing variabel dijabarkan dalam serangkaian indikator yang kemudian dikemas menjadi kuesioner. Pertanyaan dalam kuesioner menggunakan teknik pengukuran semantik diferensial yang diperkenalkan oleh Charles Osgood (1957) (dikutip dari Widiarso, 2011). Data yang diperoleh melalui pengukuran dengan skala semantik diferensial adalah data interval. Respon semantik diferensial terdiri dari 3 dimensi yaitu dimensi evaluasi, dimensi potensial, dan dimensi aktifitas. Pengolahan data menggunakan perangkat lunak Eviews.

\section{HASIL DAN PEMBAHASAN}

Responden penelitian ini kebanyakan adalah perempuan $68 \%$, sementara lakilaki sebanyak $62 \%$. Mayoritas responden adalah terdidik dengan pendidikan terakhir SLTA dan sarjana adalah mayoritas. Pekerjaan terbanyak berada di sector informal, disusul mahasiswa dan pekerja di sector formal. Sektor informal ini berupa perdagangan, peternakan dan jasa (salon, counter pulsa, rental, laundry, dan warnet), sedangkan sektor formal dalam penelitian ini terdiri dari asuransi, pegawai Kelurahan (PNS), pendidikan, transpotasi dan jasa kesehatan. Pelajar/mahasiswa menjadi dominan karena Yogyakarta adalah kota pelajar dimana terdapat banyak perguruan tinggi.

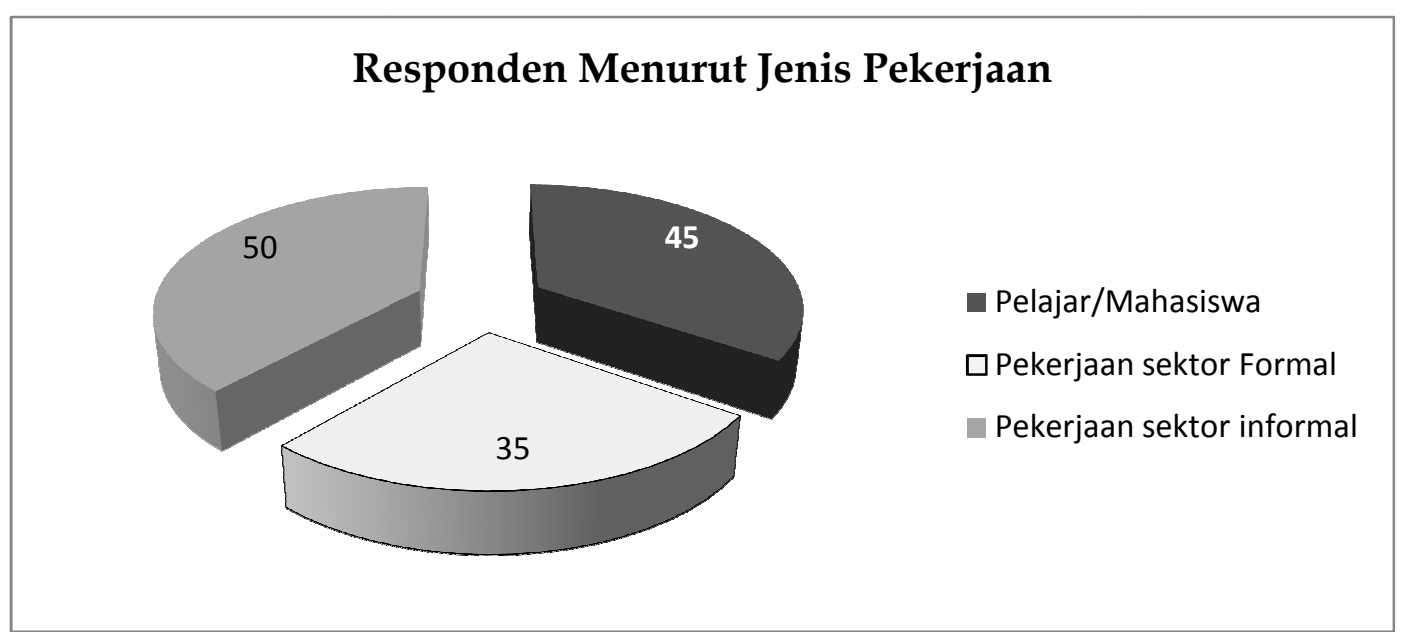

Gambar 2: Responden Menurut Jenis Pekerjaan

Sumber: Data diolah

Hasil olah data dengan eviews menunjukkan hasil sebagai berikut.

$Y=4,932-0,388 X_{1}-0,096 X_{2}-0,754 X_{3}{ }^{*}-0,117 X_{4}+0,544 X_{5}{ }^{*}$

(Z-stat) $\quad(3,433)(-1,479) \quad(-0,333) \quad(-1,999) \quad(-0,437) \quad(1,987)$

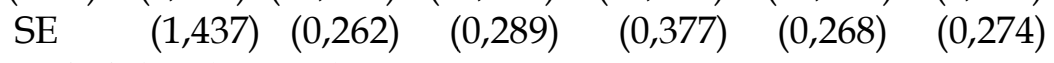

Probability (LR stat) $=0,003794$

Mac Fadden $R^{2} \quad=0,098618$

Keterangan: *) signifikan pada $\alpha=5 \%$ 
Nilai koefisien regresi logit sulit diinterprestasikan secara langsung, namun antilognya. Nilai koefisien logit 1,2549, sehingga odds ratio untuk $X_{1}, X_{2}, X_{3}, X_{4}$, dan $X_{5}$ sebesar 1,2549 . Dalam pengujian variabel independent secara simultan nilai probability (LR stat) sebesar 0,003794 maka $X_{1}, X_{2}, X_{3}, X_{4}$, dan $X_{5}$ secara simultan mempengaruhi keputusan masyarakat muslim untuk tidak memilih bank syariah. Secara individual variabel yang berpengaruh terhadap keputusan tidak memilih menggunakan bank syariah adalah $X_{3}$ dan $X_{5}$, yaitu fasilitas dan layanan serta lokasi bank syariah (pada $a=5 \%$ ). Fasilitas dan layanan dalam penelitian ini mencakup antara lain teknologi E-Banking, ATM (anjungan tunai mandiri), fasilitas kantor layanan, ragam produk yang ditawarkan, serta professionalitas karyawan bank. Lokasi bank syariah mencakup kedekatan dan banyaknya kantor layanan.

Sementara itu, $X_{1}, X_{2}$, dan $X_{4}$, yaitu faktor relijiusitas, tingkat bagi hasil deposito bank syariah, dan hadiah, tidak berpengaruh dalam keputusan tidak memilih menggunakan bank syariah.

Secara umum hasil penelitian ini konsisten dengan beberapa riset sebelumnya, terutama kuatnya pertimbangan rasional ekonomis dari masyarakat dalam memilih atau tidak memilih perbankan syariah (Alfi, 2009; Haque et.al., 2009; Misanam dan Liana, 2007; Lestari, 2006). Dari sudut pandang agama fakta ini tentu saja mengindikasikan permasalahan yang serius, sebab perbedaan antara bank konvensional dan bank syariah menyangkut suatu status hukum tertinggi, yaitu halal dan haram. Berbagai fatwa telah menempatkan bunga sebagai riba nasiah yang haram hukumnya (Mirakhor, 2009), termasuk Majelis Ulama Indonesia (MUI) dan Muhammadiyah di Indonesia. Lebih lanjut hal ini mencerminkan dua kemungkinan keadaan, yaitu: (a) masyarakat belum paham bank syariah, atau (b) masyarakat memang mengabaikan. Kemungkinan keadaan yang pertama sangat besar sebagai mana ditunjukkan oleh berbagai riset yang menunjukkan masih rendahnya pemahaman masyarakat tentang bank syariah (Norafifah and Haron, 2001; Bley, 2009). Kebanyakan masayrakat tidak benar-benar memahami apakah bank syariah dan perbedaannya dengan bank konvensioank. Kemungkinan keadaan kedua juga logis mengingat secara umum tingkat relijiusitas masyarakat Indonesia dinilai tidak tinggi. Peluncuran fatwa haramnya bunga bank oleh MUI dan Muhammadiyah, misalnya, tielk menimbulkan adanya migrasi besar besaran dari bank berbunga ke bank tidak berbunga.

Tidak berpengaruhnya tingkat bagi hasil dalam keputusan tidak memilih bank syariah mencerminkan perilaku umum masyarakat dalam memilih produkproduk perbankan. Sebagaimana dalam perbankan konvensional saat ini tingkat bunga juga bukan merupakan variabel penting yang mempengaruhi keputusan nasabah memilih bank. Apalagi tingkat bunga deposito dan tabungan saat ini relative rendah. Dalam kasus perbankan syariah tingkat bagi hasil ternyata juga bukan variabel penting dalam mempengaruhi konsumen, meskipun saat ini secara umum tingkat bagi hasil perbankan syariah di Indonesia lebih tinggi dibandingkan bunga bank deposito konvensional.

Tidak berpengaruhnya hadiah dalam keputusan masyarakat muslim untuk tidak memilih bank syariah juga merupakan fenomena menarik. Sebagaimana umumnya perbankan konvensional, kebanyakan bank syariah menawarkan hadiah untuk menarik minta masyarakat. Bentuk-bentuk hadiah yang ditawarkan perbankan syariah bervariasi, mulai dari hadiah barang (mobil, motor, rumah, dll) hingga paket-paket ibadah seperti haji dan umroh. Meskipun hadiah-hadiah ini menarik ternyata tidak menjadi pertimbangan masyarakat dalam memilih atau tidak memilih bank syariah. Temuan ini mengindikasikan bahwa perilaku masya- 
rakat relative sehat secara ekonomi, karena hadiah memang seharusnya bukan menjadi alasan rasional ekonomi untuk pemelihan produk bank.

Lokasi merupakan faktor yang berpengaruh sebagaimana juga terjadi pada masyarakat Pakistan (Hafeez, 2008) dan Uni Emirat Arab (Bley, 2009). Lokasi akan mempengaruhi akses masyarakat terhadap bank syariah, dan sebaliknya. Lokasi di sini tidak melulu mengacu pada lokasi kantor, melainkan juga anjungan layanan, misal ATM. Dengan banyaknya kantor layanan maupun ATM yang tersebar di mana-mana masyarakat akan mudah mengakses berbagai informasi dan keperluan jasa dari bank syariah.

\section{SIMPULAN DAN IMPLIKASI KEBIJAKAN}

Dari penelitian ini ditemukan bahwa yang berpengaruh terhadap keputusan untuk tidak memilih bank syariah adalah fasilitas dan layanan serta lokasi bank syariah. Kedua variabel ini merupakan hal fundamental yang mengindikasikan perilaku rasional ekonomi masyarakat. Variabel relijiusitas tidak menjadi pertimbangan berpengaruh, meskipun pertimbangan relijius untuk bank syariah berada pada level halal-haram. Kondisi ini menunjukkan dua kemungkinan: (a) masyarakat tidak paham bank syariah; dan (b) masyarakat tidak peduli pertimbangan syariah dalam menggunakan bank.

Temuan ini mengimplikasi beberapa langkah strategis yang harus dilakukan. Langkah-langkah ini adalah: (a) Masih pentingnya sosialisasi tentang perbankan syariah, termasuk di dalamnya status hukumnya dari perspektif syariah. Sosialisasi ini tentu saja bukan untuk membentuk perilaku masyarakat yang berdasarkan emosi semata, namun untuk mendudukan persoalan pada posisi yang sebenarnya. Bagi umat Islam hal yang haram adalah mutlak harus ditinggalkan; (b) Pentingnya bank syariah untuk meningkatkan kualitas dan fasilitas layanan serta sehingga setara atau lebih unggul dibandingkan konvensional. Kesepakatan dalam makna slogan iB (ai bi) yang bermakna bahwa bank syariah adalah lebih dari sekedar perbankan (beyond bank) harus dimaknaik bahwa bank syariah sekualitas bank konvensional dengan berbagai kelebihan nilai dan moralitas Islam.

\section{DAFTAR PUSTAKA}

Abduh, Mohammad and M A Omar, (2012), "Islamic Bank Selection Criteria in Malaysia: An AHP Approach", Bussines Intelligence Journal, July, Vol 5 No 2.

Bank Indonesia, (2003), Potensi dan Pengembangan Bank Syariah di Yogyakarta Laporan Akhir, Kerjasama Bank Indonesia dan Pusat Studi Ekonomi Islam (PSEI) Sekolah Tinggi Ilmu Syariah Yogyakarta.

Bank Indonesia, (2011), Statistik Perbankan Indonesia, diambil dari http://www.bi.go.id.

Bley, Jorg and Kuehn, (2009), “Convensional Versus Islamic Finance: Student Knowledge and Perception in the United Arab Emitrates", International Journal of Islamic Finance Services, Vol. 5, No.4.

Damodar, Gujarati (2006), Dasar-Dasar Ekonometrika, Edisi Ketiga Jillid 1, Erlangga, Jakarta.

Dusuki, Asyraf Wajdi and N Irwani Abdullah, (2007), "Why do Malaysian Customer Patronise Islamic Banks?", International Journal of Bank Marketing, vol 25 no 3 
Hafees and Ahmed (2008), "An Emirical Analysis of the Determinans of Bank Selection in Pakistan A Customer View", Pakistan Economic and Social Review, Volume 46, No. 2, pp. 147-160,

Haque, Ahasanul. et. al (2009), "Factor Influences Selestion of Islamic Banking: A Study on Malaysian Customer Preferences", American Journal of Applied Sciences, 6 (5):922928,

Lestari, Indah (2009), "Program Studi Ekonomi Islam: Perspektif Mahasiswa (Sebuah Kajian Pemasaran Pendidikan)", Annual Conference Islamic Studies IX, diambil dari http://dualmode.depag.go.id/acis09/file/dokumen/IndahPiliyanti.pdf

Marimuthu, Maran, et.al., (2010), "Islamic Banking: Selection Criteria and Implications", Global Journal of Human Social Sciences, Vol 10 Issue 4 September

Misanam dan Liana (2007), “Bunga Bank, Bagi Hasil, dan Relijiusitas: Suatu Investigasi Loyalitas Nasabah Terhadap Perbankan Syariah", Jurnal Sinergi Kajian Bisnis dan Manajemen Vol. 9, No.1, Hal. 69-86

Mirakhor, Abbas, (2009), Introduction to Islamic Finance, New York: Routledge

Norafifah, Ahmad dan Sudin Haron,(2001) "Perception of Malaysian Corporate Customers Toword Islamic Banking Product and Services", International Journal of Islamic Financial Service, Volume 3, No. 4

Rais (2008), “Faktor-Faktor Yang Mempengaruhi Mahasiswa Untuk Tidak Menggunakan Bank Syariah: Studi di STIE Pengembangan Bisnis dan Manajemen", Jurnal Pengembangan Bisnis dan Manajemen, Volume VIII, No. 12 April

Subhani, M Imtiaz, et.al. (2012), " Customer Criteria for the Selection of an Islamic Bank: Evidence from Pakistan", International Research Journal for Finance and Economics, No 94

Osgood, Charles E., George Suci, \& Percy Tannenbaum, 1957, The Measurement of Meaning. University of Illinois Press,

Widhiarso, (2011) "Semantik Differensial", http://widhiarso.staff.ugm.ac.id/files/3__semantik_diferensial.pdf, Diambil 10 Januari 2011

Wijaya, Alfi (2009), “Segmentasi dan Perilaku Konsumen pada Perbankan Syariah di Yogyakarta", Jurnal Ekonomi dan Bisnis Islam, Hal 143-165. 